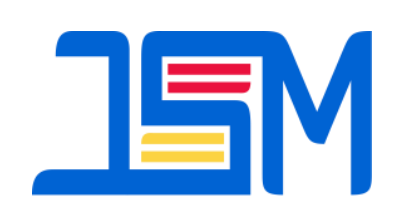

Jambura Science Of Management
JAMBURA SCIENCE OF MANAGEMENT

Homepage : http://ejurnal.ung.ac.id/index.php/jsm

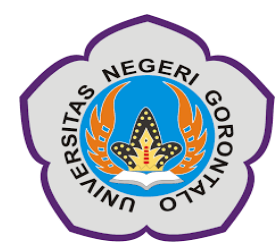

\title{
Determinant of Financial Ratio Analysis to Financial Distress
}

\author{
Setya Ayu Arini ${ }^{1}$, Yuli Chomsatu Samrotun ${ }^{2}$, Endang Masitoh ${ }^{3}$ \\ ${ }^{1,2,3}$ Economic Faculty, Universitas Islam Batik Surakarta, Indonesia \\ Jl. KH. Agussalim No. 10 Postal Code 57147 Surakarta. \\ Email: setyayuarini97@gmail.com
}

\begin{abstract}
:
In this new era bussines world is growing rapidly so that the emergence of many new companies. However, to be the market leader, the company must be able to manage the financial aspects well, so that the company does not have financial difficulties. The research aims to analyse the effects of liquidity ratios, activity ratios, profitability ratios, leverage ratios on the financial difficulties of textile and garment companies listed on the Indonesia Stock Exchange in the period 2018-2019. The object in this study used samples of 40 samples on textile and garment companies listed on the Indonesia Stock Exchange in the period 2018-2019 using sampling techniques purposive. The methods used in this study are some of the processed linear regression analyses using SPSS 25. Based on this study shows that liquidity is influential but not significant to the financial distress. The activity has significant effect on financial distress. Profitability has significant effect on financial distress. Leverage is influential but not significant to the financial distress.
\end{abstract}

\section{Keywords: Liquidity ratio; Activity ratio; Profitability ratio; Leverage ratio; Financial Distress}

Today's business world is growing rapidly resulting in many new companies emerging in an industry competing to become the market leader. However, to be a market leader, the company must be able to manage financial aspects well as a guarantee of long-term survival. The wrong management and not being careful can make the company closer to the financial problems. Company experiencing financial distress if not immediately overcome by correct policy will result in bankruptcy.

Financial Ratio analysis can be one of the tools to predict financial difficulties (financial distress) used to measure the health of the company. Financial difficulty conditions (financial distress) occurred before bankruptcy. The unpreparedness of the company in predicting the financial distress is one of the causes of bankruptcy. Financial difficulties began when the 
company was unable to fulfill the payment schedule or when the projection of cash flows indicated that the company would soon be unable to fulfill its obligations (Fachrudin, 2008:2). The financial distress condition is the decline in the financial condition of the company that occurred before the bankruptcy or liquidation (Widarjo and Setiawan, 2009). This financial difficulties prediction Model is expected to improve conditions before it comes to the stage of crisis. The financial ratios used in this study as a reference to predicting the financial distress are using liquidity ratios, profitability, leverage, activity and growth.

The difference in this research with previous research is that the company used as a research object is a textile and garment company. The selection of textile and garment companies as a research object is based on the reason that the economic crisis of the homeland is triggered by the high import of textile and garment production in the year 2019. Some challenges regarding imports, such as the price of Indonesian textile products are not competitive compared to imported products and import growth of fabrics that do not offset the export of garments. Therefore, this is also damaging the fabric, yarn and fiber industries, as well as the growth of domestic consumption taken by imports. BPS Data that processed by Kemenperin shows that in the period 2017 - 2019, the number of garment products imports reached US \$2.38 billion. In addition, in the same period there was an increase in the volume of imported carpets and other textile floor coverings with a trend of $25.2 \%$. In 2017, import volume of this product reached 21,907 tons, then at 2018 rose $31 \%$ to 28,706 tons, and at 2019 rose back by $19.7 \%$ to be 34,357 tons. The importing countries include China, Turkey, South Korea, and Japan. Furthermore, increased imports also occurred in Muslim fashion products. Hoods and scarves, for example, have a surge in imports since 2016 - 2018, from 7,000 tonnes to 12,000 tonnes.

On the other hand, not to be denied, the price of imported products is cheaper than local products. Therefore, to protect the domestic industry TPT, Kemenperin called for the rule of safeguard which is a kind of tariff import duty to the importation of TPT. "Kemenperin will provide protection through the implementation of safeguard for garment industry. This Safeguard we propose because there is an increase in imports in this sector in the last three years, "explained the director general of Industrial Small, medium, and Aneka (IKMA) Kemenperin, Gati Wibawaningsih, through its description in Jakarta as reported by Antara.

"The high number of imports in this sector is something that must be addressed seriously by Kemenperin. This high import can close the potential of the domestic market because the imported products are relatively cheap, "said Gati. This safeguard rule becomes very important considering the TPT industry has the potential to encourage the country's economy. This indicates that the company is unable to generate profit. One of the causes of profit drops is due to a reduced sales or decline. It will eventually exacerbate the condition that the textile and garment companies that are not closed will 
likely have financial difficulties even failure in its efforts.

Financial distress is a broad concept consisting of several situations where a company is facing a problem of financial difficulties. Covering the Platt and Platt (2002) in Widhiari and Merkusiwati (2015) financial distress which is the process of declining the financial position of the company that was experienced before the company was bankrupt or liquidation. Wurck (1990) in Manurung (2012) defines the financial distress as a situation where cash flow cannot be fulfilled to pay the current obligation. Fallahpour (2004) in Kordestani, Biglari, and Bakhtiari (2011), stated that the financial distress occurred in the company whose profitability decreased. With the declining profitability, the company's ability to pay the underlying loan and interest from the loan will decline.

Liquidity can be used to predict the occurrence of financial distress. The liquidity ratio is a ratio that measures the company's ability to fulfill its overdue shortterm obligations. The usual liquidity used in various studies is the current ratio. The Current ratio is a ratio that demonstrates the ability of the company to fulfill its shortterm obligations by using current assets (Hendra, 2009:199).

Profitability is also one of the factors that can affect the financial distress. Profitability shows high scores can give the company signal in good condition and not experience the financial distress. Research conducted in Serbia shows that profitability has a significant effect on the financial distress (Raden, 2015). The results of this study differ from the research that in
Indonesia shows that profitability has no significant effect on the financial distress (pure, 2018). 2 In addition to liquidity, leverage and profitability, activities can also be a contributing factor to the financial distress. The management of the company cannot maximize the use of assets and sales is not maximal can bring the company closer to financial threat distress. Research conducted in Indonesia shows that the activity has a significant effect on the financial distress (Ariawan, 2017). The results of this research is different from that done in Indonesia shows that activity has no significant effect on the financial distress (ASSAGAF, Murwaningsari, Gunawan and Mayangsari, 2019).

This research was conducted on textile and garment companies listed on Indonesia Stock Exchange period 20162019. The textile and garment industry is currently facing a challenge while facing pressure amid globalization for free trade. The enforcement of a free trade agreement between Indonesia and some countries provides heavy enough pressure for the national textile industry, especially in the market. In addition, many competitors and various factors can make the company bankruptcy if it does not implement the right strategy. Based on the contradictory results of previous research the research will reexamine the Financial Distress prediction factor in Textile and Garment companies in Indonesia.

\section{METHOD}

The type of research used in this study is quantitative research. The 
population in this research is a textile and garment company listed on the Indonesia Stock Exchange in 2016-2019. The sample selection technique used in this study is the purposive sampling method and acquired 13 samples of 21 textile and garment companies listed on the Indonesia Stock Exchange in 2016-2019. The data analysis techniques used are statistical analyses including classical assumption trials, multiple linear regression, model feasibility testing, hypothesized testing and coefficient of determination test

\section{Variablel Research and operational definitions}

The variables in this study are:

a. Bound variable (Y) financial distress

b. Free variable $(\mathrm{X})$ i.e. Liquidity ratio, Activity ratio, Profitability ratio, Leverage ratio

The operational definitions in this study can be described as follows :

a. Financial Distress (Y)

Financial Distress is a company confilled experiencing financial difficulties and threatened bankrupt (Atmaja, 2008:258). In this research the company is stated to be in the financial condition distress measured using the interest coverage ratio as a measuring instrument in measuring the financial distress of a company (Latif and Triyanto, 2018). The interest coverage ratio compares the profit before interest and taxes with the interest expense. Here's the indicator:

Interest coverage ratio :

$\frac{\text { EBIT }}{\text { Interest expense }}$

b. Liquidity Ratio (X1)

Liquidity describes the company to pay the obligations that should be fulfilled immediately (Sutrisno,2013:222). Research on the liquidity ratio is measured using the current ratio. Current ratio is the comparison between the number of current assets with smooth debt (MUNAWIR,2012:72). Here's the indicator:

Current Ratio :

Current assets

Current debt

c. Activity Ratio (X2)

The activity ratio shows the company's ability to effectively use assets (cashmere,2014:172). In this study the activity ratio was measured using the asset turnover ratio (Harahap,2011:308). This ratio is expressed as a comparison of sales or revenue with total assets. Here's the indicator:

Total Asset Turnover Ratio:

$\frac{\text { Sales/Revenue }}{\text { Total assets }}$

d. Profitability Ratio (X3)

The profitability ratio is a ratio that shows the company's ability to generate profit in a given period (MUNAWIR, 2012:33). Profitability 
is stated by the term return on asset (cashmere, 2014:197). Return on asset (ROA) is measured by a comparison of net income after tax with total assets (cashmere, 2014:197). Here's the indicator:

Return on Assets :

\section{EAT \\ Total assets}

c. Laverage Ratio (X4)

The ratio of the laverage showed that the company's funds were budgetfunded (Sutrisno, 2013:224). In this study the ratio of laverage was measured using debt ratio. This ratio compares between the total debt companies has with the total assets (cashmere, 2014:151). Here's the indicator:

Debt Ratio :

\section{Total debt}

\section{Total Assets}

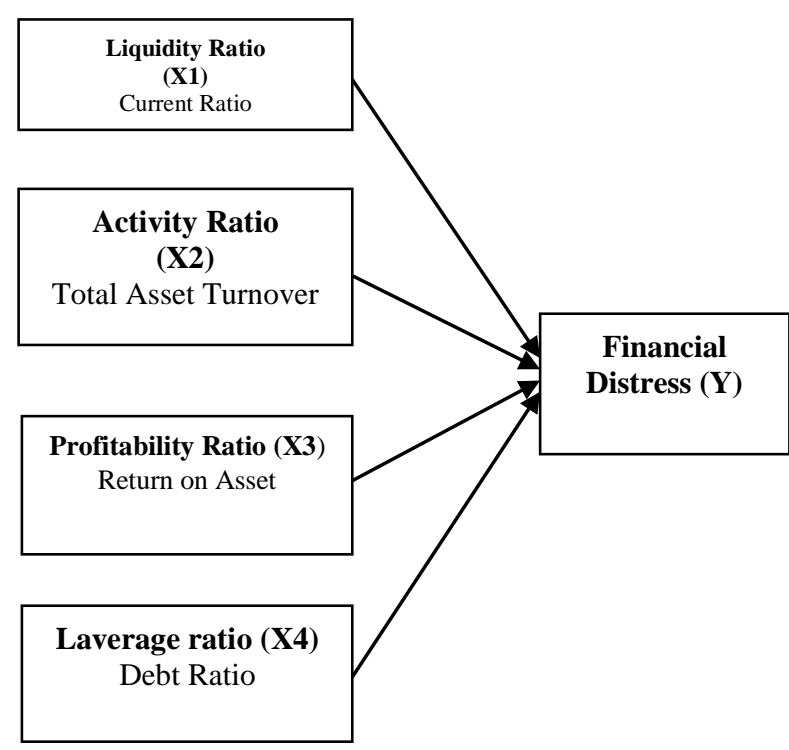

\section{RESULT}

\section{Picture 1. Hipotesa}

\section{Classic Assumption Test Test Result Normality}

Test normality aims to test in a regression model, the interrupt variable or the residual has a normal distribution. This test uses the Kolmogrove Smirnov test. The test results can be seen in the table below:

Tabel 1.

Test Result Normality

\begin{tabular}{lll}
\hline & $\begin{array}{l}\text { Unstandariszed } \\
\text { Residual }\end{array}$ & Std. \\
\hline $\begin{array}{l}\text { Asymp.Sig } \\
\text { (2 tailed) }\end{array}$ & 009 & 0,05 \\
\hline
\end{tabular}

The test results show Asymp. Sig. (2-tailed) $(0.09)>0.05$. This means that the regression equation has normal spreads or variations of data.

\section{Multicolinearity Test Results}

Multicolinearity Test Results aims to test regression models found the correlation between the free variables. A good regression model does not occur in correlation between free variables. Detecting the presence or absence of multicolinearity in regression can be seen from the magnitude of tolerance and its opponent. If tolerance value $>0.10$ and VIF $<10$ Then there is multicolinearity. Multicolinearity test results can be seen in the table below:

Tabel 2.

Multicolinearity Test Results

Variabel Tolerance Std.




\begin{tabular}{llll}
\hline Liquidity & Ratio & 0,851 & \\
Activity & Ratio & 0,817 & $>0,1$ \\
Profitability & Ratio & 0,763 & \\
Laverage & Ratio & 0,731 & \\
\hline
\end{tabular}

Based on the calculation results in the table above, obtained the value tolerance liquidity variable 0.851 , the value tolerance activity variable 0.817 , the value of tolerance variable provitability 0.763 and the value tolerance Laverage 0.731 which all $>0.10$. So the regression model on this research there is no multicolinearity between variables freely.

\section{Heteroskedastisity Test Results}

Heteroskedastisity Test Results are used to test the presence of heterokedastisity in research using Glejser test. There is no heterokedastisity known by seeing its significance against the degree of confidence $5 \%$. Heterokedastisity test results with Glejser test can be shown in the following table:

Tabel 3.

\begin{tabular}{lll}
\multicolumn{3}{c}{ Heteroskedastisity test Results } \\
\hline Variabel & Sig. & Std. \\
\hline LiquidityRatio & 0,784 & \\
ActivityRatio & 0,530 & $>0,05$. \\
ProfitabilityRatio & 0,375 & \\
Laverage Ratio & 0.805 & \\
\hline
\end{tabular}

Based on the table above shows that the probability value (Sig.) of each independent variable is 0.209 worth of liquidity, activity worth 0.989 , profitability is worth 0.001 , and laverage is worth 0.434. Can be declared this regression model does not occur heterokedastisity.

\section{Autocorrelation Test Results}

Autocorrelation Test Results aims to determine whether the correlation between members of a series of observations is sorted by time or space, means that the outcome of a given year is influenced by the previous or subsequent year. The autocorrelation test results can be shown in the following table:

\section{Tabel 4.}

Autocorrelation Test Results

\begin{tabular}{ll}
\hline Durbin-Watson & Std. \\
\hline 1.720 & $\mathrm{dU}<\mathrm{DW}<4-\mathrm{dU}$ \\
\hline \multicolumn{2}{c}{ According to the table above, you }
\end{tabular}
can see Durbin-Watson value is 1,720. The value of Durbin-Watson resides in the $\mathrm{dU}$ area $<1,720<4-\mathrm{dU}$, so that the regression model can be summed up from the autocorrelation problem and is worth using.

Multiple Linear Regression Results

Values $\mathrm{A}$ and $\mathrm{B}_{1}, \mathrm{~b}_{2}, \mathrm{~b}_{3}$ in a double linear regression test are:

Tabel 5.

Multiple Linear Regression Results

\begin{tabular}{ll}
\hline Model & $\mathrm{B}$ \\
\hline Constant & -163.566 \\
LiquidityRatio & 0,229 \\
ActivityRatio & 2.436 \\
ProfitabilityRatio & -48.136 \\
Laverage Ratio & $-0,625$ \\
\hline
\end{tabular}

Based on the similarities are:

$\mathrm{Y}=-163.566+0.229 \mathrm{Lik}+2.436 \mathrm{Lev}-$ 48.136Pro - 0.625Akt

Model Feasibility Test Results

The calculation of the Fhitung value is:

Tabel 6.

Model Feasibility Test Results

\begin{tabular}{|c|c|c|c|}
\hline Fhitung & $F_{\text {tabel }}$ & Sig. & Std. \\
\hline 15.344 & 2.87 & $0.000^{\mathrm{a}}$ & $<0.05$ \\
\hline
\end{tabular}
obtained, then it can be known that the value Fhitung is charge of 15.344, because Fhitung > Ftabel $(15.344>2,02)$ and significant $0.00<$ 
0,05 Then the model deserves use. This means that there is a significance influence between liquidity ratio, leverage ratio, profitability ratio and simultaneous activities ratio of financial distress.

Hypothesis Test Results

Tabel 7.

Hypothesis Test Results

\begin{tabular}{lcccc}
\hline Hypothesis & t $_{\text {count }}$ & table & Sig. & \multicolumn{2}{c}{ Std. } \\
\hline H1:LiquidityRatio & 1.861 & 2.028 & 0.071 & \\
H2:ActivityRatio & 2.033 & 2.028 & 0.050 & $<0.05$ \\
H3:ProfitabilityRatio & -6.546 & -2.028 & 0.000 & \\
H4:Laverage Ratio & -1.092 & -2.028 & 0.282 & \\
\hline
\end{tabular}

Value tabel $<$ thitung $(1.861<2.028)$

and value of significance $0.071>0.05$ then $\mathrm{H} 1$ rejected. The liquidity variable can be concluded no effect on the financial distress. Value tabel $<$ thitung $(2.033>2.028)$ and value of significance $0.05>0.05$ then $\mathrm{H} 2$ accepted. Inconclusive activity variables impact on financial distress. Value ttabel < thitung $(-6.546<-2.028)$ and value of significance $0.00<0.05$ then $\mathrm{H} 3$ accepted. Can be concluded there is significant influence of profitability on financial distress. Value tabel < thitung $(-1.092<-$ 2.028) and value of significance $0.28<0.05$ then $\mathrm{H} 4$ rejected. Can be concluded no significant effect of laverage on financial distress.

\section{Coefficient Test Result Determination}

The Adjusted value of R Square ( $R$ 2) amounted to 0595 or $59.5 \%$. This means that liquidity variables, leverage, profitability and activities have an impact of $59.5 \%$ on the financial distress. The remaining $40.5 \%$ is influenced by other variables such as company size, good corporate governance, business risk, inflation, management policy and others.

\section{DISCUSSION}

In the results of this research the liquidity variables measured using the $\mathrm{CR}$ (current ratio) show the results of the Sig. 0071 is greater than 0.05 which means it has no effect on the current ratio of CR (recent) to financial distress. The following can be concluded that companies having book CR (current ratio) large or small can experience financial distress. CR (current ratio) is increasing in the presence of elements of the low current assets of liquidity, e.g. increased preparations or accumulating. One of the reasons that make Variabeon the research results of the liquidity variables measured using CR (current ratio) shows the results of the Sig. 0071 is greater than 0.05 which means it has no effect on the current ratio of CR (the) of financial distress. The following can be concluded that companies having book CR (current ratio) large or small can experience financial distress. CR (current ratio) is increasing in the presence of elements of the low current assets of liquidity, e.g. increased preparations or accumulating. One reason that makes liquidity variable has no effect on the financial distress is the current property of the company used for the purpose of paying interest, paying debts, financing daily operations, so that the company is not effective in rotating the current property if it is protracted will cause financial distress. This research has been conducted by Nakhar Nur Aisyah (2017) and Hidayat and Meiranto (2014) with the results of the same research and in line. L Liquidity has no effect on the financial distress is the current property of the company used for the 
purpose of paying interest, paying debts, financing daily operations, so the company is not effective in turning the current asset if it is protracted This research has been conducted by Nakhar Nur Aisyah (2017) and Hidayat and Meiranto (2014) with the same and the same results of research.

The activity ratio variable that is measured by the total asset turnover ratio (TATTO) is getting the significance of the 0.05 equivalent to 0.05 which means the ratio of activity has an influence on financial distress. This indicates that if a company has a large or small amount of asset turnover, it can experience financial distress. If the higher asset turnover the more effective also the company's assets that produce sales, but that is worth noting is the expenditure to avoid the occurrence of financial distress, because some companies if the company Sudiono (2013).

The measured profitability ratio variable using (return on assets) ROA shows a significance result of 0.00 less than 0.05 which means that the profitability ratio has a significant influence on the financial distress. The ratio of profitability measured by the return on assets of ROA is a ratio that can measure the effectiveness and efficiency of the company ' s use in profit making, with the efficiency and effectiveness of an asset owned by the company can be more optimal in generating profit, has the adequacy of funds to charge the cost to run the business. With the fulfillment of the cost of the company to experience the financial distress very small. The results of this study were in line with the research of Saleh and Sudiyanto (2013). The variable laverage ratio measured by the DER (debt to asset ratio) method resulting in a significance value of 0.28 less than 0.05 this indicates that the laverage ratio has no effect on the financial distress. The company does not require a lot of outside funds to run all operations, so it can minimize financial distress. Companies in research samples can carry out their operations without using outside funds including debts, the company also conducts overdue debt payments so that the company can maintain business continuity. The results of this study were in line with Choifina and Yuyetta (2015).

\section{CONCLUSION}

The liquidity ratio, activity ratio, profitability ratio, and laverage ratio are condemned by Multiple linear regression and using IBM SPSS statistics 25 generates data that the liquidity is influential but not significant to the financial distress. The activity has significant effect on financial distress. Profitability is significant with the financial distress. Leverage is influential but not significant to the financial distress in textile and garment companies listed on the Indonesia Stock Exchange in 2016-2019.

\section{RECOMMENDATION}

Based on the conclusion above, then in this research researchers are expected to increase the combination of different ratios and longer research periods so as to develop this research. It is also expected to add a sample of companies to be researched, such as using the company sector listed on the Indonesia Stock exchange in hopes of better earned results. 


\section{REFERENCES}

Ariawan, Y. (2017). Pengaruh Faktor-Faktor Penentu Financial Distress Pada Perusahaan Properti yang Terdarfar di BEI. Artikel Ilmiah Universitas Tarumanegara, 1-15

Assagaf, A., Murwaningsari, E., Gunawan, J., dan Mayangsari, S. (2019). Estimates Model of Factors Affecting Financial Distress: Evidence from Indonesian State-owned Enterprise. Asian Journal Economics, Business and Accounting 11(3), 1-19.

Atmaja, L.S. (2008). Teori \& Praktik Manajemen Keuangan. Yogyakarta: Andi Offset.

Fachrudin, Khaira Amalia. 2008. Kesulitan Keuangan Perusahaan dan Personal. Medan: USU Press

Choirina, P.M., \& Yuyetta, E.N.A. (2015). Analisis Faktor-Faktor yang Mempengaruhi Probabilitas Financial Distress Perbankan Indonesia. Diponegoro Journal of Accounting 4(2), 1-9.

Ghozali, I. (2015). Aplikasi Analisis Multivariate dengan Program SPSS. Semarang: Badan Penerbit Universitas Diponegoro.

Ghozali, Imam. (2013). Aplikasi Analisis Multivariate dengan Program IBM SPSS 19. Semarang: BP Universitas Diponegoro.

Hapsari, Evanny Indri. (2012). Kekuatan Rasio Keuangan Dalam Memprediksi Kondisi Financial Distress Perusahaan Manufaktur di BEI. Jurnal Dinamika Manajemen Vol.3, No. 2, 101-109.
Hery. (2015). Analisis Laporan Keuangan. Yogyakarta: CAPS.

Hery. (2016) Analisis Laporan Keuangan. Jakarta: PT Gramedia Widiasarana.

Hidayat, M.A., \& Meiranto, W. (2014). Prediksi Financial Distress Perusahaan Manufaktur di Indonesia. Diponegoro Journal of Accounting 3(3), 1-11.

Kasmir. (2014). Analisa Laporan Keuangan. Jakarta: Raja Grafindo Persada

Kodestani, Gholamreza., Vahid Biglari., dan Mehhrdad Bakhtiari. (2011). Ability of Combination of Cash Flow Components to Predict Financial Distress : Theory and Practice. Vol. 12, No. 3 277-285

Manurung, Adler Haymans. (2012). Teori Keuangan Perusahaan, Jakarta: PT Adler Manurung Press

Munawir, S (2012). Analisa Laporan Keuangan. Yogyakarta: Liberty

Murni, M. (2018). Analisis Faktor-Faktor yang Mempengaruhi Tingkat Financial Distress Pada Perusahaan Manufaktur yang Terdaftar di BEI Tahun 2010- 2014. Jurnal Akuntansi dan Bisnis 4(1), 74-83.

Nakhar Nur Aisyah (2017) Pengaruh Rasio Keuangan terhadap Financial Distress. Universitas Telkom

Plat, H. D., dan Platt, M. B. (2002). Predicting Financial Distress Journal of Financial Service Professionals, 56(3), 12-15

Raden, D. (2015). The Analysis of the Effects of Financial Distress on The Top Management in The Republic of Serbia. The European Journal of Applied Economics 12(1), 19-25. 
Sari, I.P., Susbiyani, A., \& Syahfrudin, A. (2019). Analisis Faktor-Faktor yang Mempengaruhi Kondisi Financial

Saleh, Amir dan Sudiyatno, Bambang. (2013). Pengaruh Rasio Keuangan untuk Memprediksi Probabilitas Kebangkrutan pada Perusahaan manufaktur yang terdaftar di Bursa Efek Indonesia. Dinamika Akuntansi, Keuangan dan Perbankan, Vol.2 No.1 2013.

Santoso, Singgih. (2014). Statistik Multivariat. Jakarta: PT Kompas Gramedia

Sawir, Agnes, 2009. Analisa Kinerja Keuangan dan Perencanaan keauangan Perusahaan. Jakarta: PT. Gramedia Pustaka Utama.

Sudiono. (2013) Metode Penelitian Manajemen Bandung: Alfabeta

Sekaran, Uma. (2011). Metodologi Penelitian untuk Bisnis. Yogyakarta: Salemba Empat.

Sugiyono. (2013). Metode Penelitian Manajemen. Bandung: Alfabeta.

Sugiyono (2012). Metode Penelitian Kuantitatif, Kualitatif dan R\&D. Bandung: Alfabeta.

.2
Sutrisno. (2013). Managemen Keuangan. Yogyakarta: Ekonisia Fakultas Ekonomi UII.

Wasis. (2013). Manajemen Keuangan Perusahaan. Semarang: Satya Wacana.

Widarjo, Wahyu dan Setiawan Doddy. (2009). Pengaruh Rasio Keuangan Terhadap Kondisi Financial Distress Perusahaan Otomotif. Jurnal Bisnis dan Akuntansi Vol. 11, No.2, 107119.

Widhiari, Ni Luh Made Ayu dan Merkusiwati, Ni K. Lely Aryani. (2015). Pengaruh Rasio Likuiditas, Leverage, Operating Capacity, dan Sales Growth Terhadap Financial Distress. E-Jurnal Akuntansi Universitas Udayana, 11.2(2015), 456-469.

Widjajanta. (2007). Mengasah Kemampuan Ekonomi. Citra Praya. Bandung

Wongsosudono, Corinna dan Chrissa. (2013). Analisis Rasio Keuangan untuk Memprediksi Financial Distress pada Perushaan Sektor Keuangan yang Terdaftar di Bursa Efek Indonesia. Jurnal Bina Akuntansi IBBI, Vol 19 No 